\title{
COVID 19 with false negative RT-PCR test in 4 patients: When Chest CT becomes a need.
}

\author{
Mariam Kassimi, Rita Filali, Nabil Chikhaoui, Mohamed Mahi \\ Faculty of Medicine, Mohammed VI University of Health Sciences (UM6SS), Casablanca, Morocco. \\ Cheikh Khalifa International University Hospital, Mohammed VI University of Health Sciences (UM6SS), Casablanca, Morocco. \\ DOI: $10.29322 / I J S R P .10 .06 .2020 . p 10284$ \\ http://dx.doi.org/10.29322/IJSRP.10.06.2020.p10284
}

\begin{abstract}
Objectives: To describe CT imaging features of 4 patients with initial negative RT-PCR results but high suspicion of COVID-19 infection.

Materiel and methods: Retrospective study including patients with COVID-19 pneumonia who underwent both CT and RT-PCR at initial presentation in our institution From March 31th, 2020 to april $27^{\text {th }}$. The results of both tests were compared. For patients with a final confirmed diagnosis, clinical, laboratory data and CT imaging findings were evaluated.

Results: From 142 laboratory confirmed cases, a total of four patients had an initial negative RT PCR and positive CT findings .3 patients were diagnosed in early stage (1-5days) and one in progressive stage (5-8 days).

The 4 patients had typical imaging findings, including groundglass opacity (GGO) (2 patients), crazy paving (1 patient),mixed GGO and crazy paving (1 patient). All the patients were isolated After for presumed 2019-nCoV pneumonia and they were eventually confirmed with $2019-\mathrm{nCoV}$ infection by repeated swab tests.
\end{abstract}

Conclusion: rRT-PCR may produce false- negative results in the early stages of the disease mostly. We therefore suggest that CT features could be utilized as the immediate reference to screen the highly suspected cases and to take necessary actions, while rRTPCR serves as a confirmation tool to decide the subsequent action of continuing isolated treatment or discharge.

Key points:

- Typical radiological presentation with high clinical suspicion of 2019-nCov infection should be considered even do negative RT-PCR results .

- In these cases,repeat swab testing and patient isolation should be applicable.

Index Terms- Pneumonia, Tomography ,Coronavirus, disease

\section{INTRODUCTION}

$\mathrm{I}_{\mathrm{i}}^{\mathrm{n}}$ December 2019, an outbreak of 2019-nCoV pneumonia began in Wuhan (Hubei, China) and spread rapidly(1). Definite diagnosis relies on real-time reverse-transcriptase- polymerase chain reaction (rRT-PCR) positivity for the presence of coronavirus [2,3]. Because of the strong infectivity of COVID-19, rapid and accurate diagnostic methods are urgently required to identify, isolate and treat the patients as soon as possible needed to reduce the risk of public contamination. However, the sensitivity to detect COVID-19 of real time (RT)-PCR is reported to be lower than that of chest $\mathrm{CT}$;We report here four false negative results of (rRT-PCR) with typical chest CT findings of covid 19 to discuss complementary of the two techniques .

\section{RESEARCH ELABORATION}

This study was approved by the Ethics Committee of our institution. Signed informed consent was obtained.

Type of study:

A retrospective study carried out in our institution From March 31 th, 2020 to april $27^{\text {th }}$.

Participants:

Inclusion criteria were as follows:

1- Patients with a fever and COVID-19 pneumonia suspicion.

2-who underwent both thin-section CT of the chest and rRT-PCR examinations in our institution on the same day.

Exclusion criteria: Patients who had performed initial RT PCR and /or chest CT in another institution, transferred to another hospital or lost to follow-up.

Laboratory confirmed 2019-n Cov patients in the database of the department of radiology of our institution were collected .Diagnosis of covid 19 was determined according to following three methods:isolation of 2019 ncov or at least 2 positive results by RT-PCR assay fo 2019-nCov or a genetic sequence that matches $2019-$ nCov.

Available clinical history; laboratory and epidemic characteristic were collected. All patients underwent CT scanning on the same day when initial nasopharyngeal swab test was performed.

\section{Image interpretation:}

Examinations were performed on a 64-section scanner. Images were reconstructed with a $1,25 \mathrm{~mm}$ slice thickness, using a high frequency reconstruction algorithm. Acquisitions were performed during a deep inspiration breath-hold, without contrast administration.

Radiology Team, retrospectively reviewed all chest CT images and resolved discrepancies by consensus.

Both lung (width, $1500 \mathrm{HU}$; level, -700 HU) and mediastinal (width, $350 \mathrm{HU}$; level, $40 \mathrm{HU}$ ) settings were viewed for all images . 
Different patterns were analyzed ground-glass opacities (GGO), consolidation, mixed GGO and consolidation, traction bronchiectasis, bronchial wall thickening, reticulation, subpleural bands, vascular enlargement and lesion distribution. The detailed definitions of the above features were as described in (6).

Corads system ,CT involvement score (CT severity score )and CT stagging of the infection were also analyzed using"radiology assistant platform (11).

\section{RESULTS AND FINDINGS}

From 142 laboratory confirmed cases, a total of four patients ( All women; age range :48-60 years ) had an initial negative RT PCR and positive CT findings. (Fig 1)

After positive CT findings, all patients were isolated for presumed 2019-nCov pneumonia. Repeat rRT-PCR tests was performed in all patients.

In 8 patients, CT was initially negative while RT-PCR was positive. In 130 patients both Rt-PCR and CT were concordant for covid 19.

Of the four patients with negative RT-PCR and positive CT at initial presentation, the highest $\mathrm{CT}$ involvement score was $26 \%-49 \%$ while the minimum was $<5 \%$.

In our four patients both CT scan and initial RT-PCR were performed between 4 and 5days after symptom onset.

Ground glass opacities (GGO) were found in 2 patients, crazy paving (1 patient), mixed GGO and crazy paving in 1 patient.

3 patients were diagnosed in early stage(1-5days) and one in progressive stage (5-8 days).

Corads 4 was found in three patients and corads 5 in one case.

The description of 4 patients with positive CT and negative RT-PCR results are presented below (Table 1),figures 2,3,4,5.

\section{DISCUSSION}

Reverse-transcription polymerase chain reaction (RT-PCR) is the gold standard diagnostic method. False-negative results could delay the prevention and control of the epidemic, especially when this test plays a key reference role in deciding the necessity for continued isolated medical observation or discharge(4).Regarding underlying reasons for false-negative rRT-PCR results, a previous published study supposed that insufficient viral specimens and laboratory error might be the cause (5).

We suggest from our study that infection phase might influence the rRT-PCR test accuracy .

Recent studies have shown that chest CT findings could be present even before the onset of symptoms with high sensitivity (98\%) in COVID-19 patients with false negative RT-PCR results, and it shows a great importance in early diagnosis $(9,10)$.

In our four patients, we found that the $\mathrm{CT}$ diagnosis was made in early( 3 patients) or progressive stage (1 patient) of the disease .

We have to notice that all patients have shown mild to moderate clinical manifestations concordant with CT severity score of all of them.
These findings support the fact that chest CT is performant for diagnosis of covid 19 in early phases (1-5days).

In our study the most common chest CT finding is GGO in 3 patients with lower lobe involvement in all of them.

Wich is compatible with most of the previous radiological studies $(10,12)$.

False-negative rRT-PCR results were seen in many hospitals. By Collecting data at our hospital from march 21 to April 23, 2020, four out of 142 patients false negative cases shown by the rRT-PCR test were finally confirmed to be positive for COVID-19, yielding an approximately $2,8 \%$ false-negative rate of rRT-PCR

A new diagnostic type called "Clinical diagnosis" was set according to the presence of pneumonia on chest CT, regardless of rRT-PCR results(5). To some extent, CT features and rRT-PCR results were complimentary in the diagnosis of COVID-19 (4).

In conclusion and according to this clinical perspective, CT features could be utilized as the first and immediate reference to screen the highly suspected cases and to take necessary actions while rRT-PCR serves as a confirmation tool, the results of which could be utilized later to decide the subsequent action of continuing isolated treatment or discharge.

This study had some limitations mainly the sample size of this study was small .Larger sample sizes are therefore required for further verification.

\section{CONCLUSION}

According to this clinical perspective, CT features could be utilized as the first and immediate reference to screen the highly suspected cases and to take necessary actions while rRT-PCR serves as a confirmation tool, the results of which could be utilized later to decide the subsequent action of continuing isolated treatment or discharge.

This study had some limitations mainly the sample size of this study was small .Larger sample sizes are therefore required for further verification.

\section{REFERENCES}

[1] 1.World Health Organization. Novel coronavirus - China. available a http://www.who.int/csr/don/12- january-2020-novel-coronavirus-china/en/ (accessed Jan 19, 2020)

[2] 2. Corman VM, Landt O, Kaiser M et al. detection of 2019 novel coronavirus (2019-nCoV) by real-time RT-PCR,Euro Surveill doi: 10.2807/1560 7917.

[3] 3. Rubin EJ, Baden LR., Morrissey S et al . medical Journals and the 2019nCoV Outbreak.N Engl J Med doi: 10.1056/NEJMe2001329

[4] 4.Dasheng L, Dawei W, Jianping.D et al .false-Negative Results of RealTime Reverse- Transcriptase Polymerase Chain Reaction for Severe Acute Respiratory Syndrome Coronavirus 2:Role of Deep-Learning-Based CT Diagnosis and Insights from Two Cases. Korean J Radiol 2020;21:505-508 .

[5] 5.Xie X, Zhong Z, Zhao W et al. chest CT for typical 2019-nCoV pneumonia: relationship to negative RTPCR testing. Radiology 2020;12:200-343. doi: 10.1148/radiol.2020200343

[6] 6. Ajlan AM, Ahyad RA, Jamjoom LG et al. middle East respiratory syndrome coronavirus (MERS-CoV) infection: chest CT findings.AJR 2014;203:782-787.

[7] 7. Feng P, Tianhe Ye,Peng S et al.time Course of Lung Changes On Chest CT During Recovery From 2019 Novel Coronavirus (COVID-19) Pneumonia . Radiology 2020;13:200-370. doi: 10.1148/radiol.2020200370 
[8] 8.Mathias P, Wouter V, Tjalco V et al .the "COVID-19 Standardized Reporting" Working Group of the Dutch Radiological Society .CO-RADS A categorical CT assessment scheme for patients with suspected COVID-19: definition and evaluation . Radiology 2020 ;27:201-473. doi: 10.1148/radiol.2020201473.

[9] 9. Wang D, Hu B, Hu C et al. clinical characteristics of 138 hospitalized patients with 2019 novel coronavirus-infected pneumonia in Wuhan, China. JAMA 2020. doi: 10.1001/jama.2020.1585.

[10] 10. Bernheim A, Mei X, Huang M, Yang Y, Fayad ZA et al. ct imaging features of 2019 novel coronavirus (2019-nCoV). Radiology 2020;295:202207.

[11] 11.Covid-19- The radiology assistant available at : https://radiologyassistant.nl/chest/lk-jg-1.

[12] 12. Ai T, Yang Z, Hou H and al. correlation of Chest CT and RT-PCR Testing in Coronavirus Disease 2019 (COVID-19) in China: A Report of 1014 Cases. Radiology 2020;26:200-642. doi: 10.1148/radiol.2020200642.

\section{AUTHORS}

First Author - Mariam Kassimi,MD,

M.Kassimi91@hotmail.com.

Second Author - Rita Filali MD, R.filali.7@gmail.com.

Third Author - Nabil Chikhaoui ,PHD

(N.chikhaoui@ hotmail.com) and Mohamed Mahi , PHD,(Prmahimohamed@yahoo.fr)

Correspondence Author - Mariam Kassimi, M.Kassimi91@ @otmail.com, +212662168754 


\begin{tabular}{|c|c|c|c|c|}
\hline$\underline{\text { Patients }}$ & 1 & 2 & 2 & 4 \\
\hline$\frac{\frac{\text { AGE }}{\text { AND }}}{\text { GENDER }}$ & 54 years old female & $\begin{array}{l}48 \text { years old } \\
\text { female }\end{array}$ & $\begin{array}{l}50 \text { years old } \\
\text { female }\end{array}$ & A 60-year-old female \\
\hline $\begin{array}{l}\text { EXPOSU } \\
\text { RE } \\
\underline{\text { HISTROY }}\end{array}$ & $\begin{array}{lr}\text { Recent Travel } & \text { to } \\
\text { Epidemic } & \text { zone } \\
\text { (FRANCE) } & \end{array}$ & $\begin{array}{l}\text { Direct contact } \\
\text { with } \\
\text { Infected } \\
\text { Patient(sister) }\end{array}$ & $\begin{array}{l}\text { Recent travel } \\
\text { history to } \\
\text { ITALY } \\
\text { during the } \\
\text { 2019-nCoV } \\
\text { outbreak }\end{array}$ & $\begin{array}{l}\text { Direct contact with Her husband } \\
\text { who had been previously } \\
\text { Diagnosed } 2019 \text {-nCov. }\end{array}$ \\
\hline$\frac{\underline{\text { SYMPTO }}}{\underline{\text { MS }}}$ & $\begin{array}{l}\text { Fever with a body } \\
\text { temperature of } 38.5^{\circ} \mathrm{C} \text {. } \\
\text { Mild cough of } 5 \text { days } \\
\text { duration. }\end{array}$ & $\begin{array}{l}\text { Fever Dry } \\
\text { throat and } \\
\text { difficulty } \\
\text { breathing } \\
\text { during } 4 \text { days. }\end{array}$ & $\begin{array}{l}\text { Dry cough } \\
\text { with no fever } \\
\text { of } 5 \text { days } \\
\text { duration }\end{array}$ & $\begin{array}{l}\text { Fever } \\
\text { Loss of appetite for } 5 \text { days }\end{array}$ \\
\hline$\frac{\text { RT PCR }}{\underline{\text { TESTING }}}$ & $\begin{array}{l}\text { A negative result for } \\
\text { SARS-CoV-2 was } \\
\text { found in the first rRT- } \\
\text { PCR test. } \\
\text { A second consecutive } \\
\text { test was conducted } 24 \mathrm{~h} \\
\text { thereafter, and a } \\
\text { positive result was } \\
\text { obtained. }\end{array}$ & $\begin{array}{l}\text { Initial RT- } \\
\text { PCR for 2019- } \\
\text { nCoV was } \\
\text { negative } \\
\text { The patient } \\
\text { was kept } \\
\text { under } \\
\text { observation } \\
\text { and home } \\
\text { isolation. } 2 \\
\text { days after the } \\
\text { swab test } \\
\text { turned } \\
\text { positive }\end{array}$ & $\begin{array}{l}\text { The first swab } \\
\text { test was } \\
\text { negative and } \\
\text { the patient } \\
\text { was isolated. } \\
\text { Over the next } \\
\text { week, two } \\
\text { more swab } \\
\text { tests returned } \\
\text { negative. On } \\
\text { day 8, the } \\
\text { swab test was } \\
\text { positive. }\end{array}$ & $\begin{array}{l}\text { The patient nasopharyngeal swab } \\
\text { was initially negative she } \\
\text { was diagnosed as } \\
\text { "Presumed cases" based. on } \\
\text { early CT findings and she } \\
\text { was immediately isolated } \\
\text { The second RT-PCR test was } \\
\text { positive } 24 \text { hours after } \\
\text { admission }\end{array}$ \\
\hline $\begin{array}{l}\frac{\text { FINDING }}{\text { S ON }} \\
\frac{\text { CHEST }}{\underline{\text { CT }}}\end{array}$ & $\begin{array}{l}\text { Unilateral GGO lesion } \\
\text { in the left lower lobe } \\
\text { traction bronchectasies } \\
\text { and } \\
\text { enlargement are also } \\
\text { seen. }\end{array}$ & $\begin{array}{l}\text { Bilateral } \\
\text { peripheral } \\
\text { ground-glass } \\
\text { opacities with } \\
\text { interlobular } \\
\text { septal } \\
\text { thickening } \\
\text { (crazy-paving } \\
\text { pattern) that } \\
\text { affected right } \\
\text { lower lobe. }\end{array}$ & $\begin{array}{l}\text { slight reticular } \\
\text { pattern in the } \\
\text { left lower lobe } \\
\text { (sub pleural } \\
\text { area) } \\
\text { resembling } \\
\text { the sign of } \\
\text { crazy paving }\end{array}$ & $\begin{array}{l}\text { Ground-glass opacities } \\
\text { in the bilateral lower lobes. }\end{array}$ \\
\hline$\underline{\text { CORADS }}$ & $\begin{array}{l}\text { High level of suspicion } \\
\text { for } \\
\text { involvement by COVID- } \\
19\end{array}$ & \begin{tabular}{l}
\multicolumn{1}{c}{$\mathbf{5}$} \\
Very high level \\
of suspicion for \\
pulmonary \\
involvement by \\
COVID-19
\end{tabular} & \begin{tabular}{l}
\multicolumn{2}{c|}{$\mathbf{4}$} \\
High level of \\
suspicion for \\
pulmonary \\
involvement by \\
COVID-19
\end{tabular} & $\begin{array}{l}\text { V } \\
\text { Very high level of suspicion for } \\
\text { pulmonary involvement by COVID- } \\
19\end{array}$ \\
\hline
\end{tabular}




\begin{tabular}{|c|c|c|c|c|}
\hline$\frac{\frac{\text { CT }}{\text { INVOLVE }}}{\frac{\text { MENT }}{\text { SCORE }}}$ & $<5 \%$ involvement & $\begin{array}{l}26 \%-49 \% \\
\text { involvement }\end{array}$ & $<5 \%$ & $5 \%-25 \%$ involvement \\
\hline $\begin{array}{l}\frac{\text { CT }}{\text { STAGE OF }} \\
\underline{\text { INFECTIO }} \\
\underline{N}\end{array}$ & Early & Progressive & Early & Early \\
\hline
\end{tabular}

\section{Table 1: The demographic characteristics, initial symptoms, RT-PCR results and CT findings of our 4 patients.}

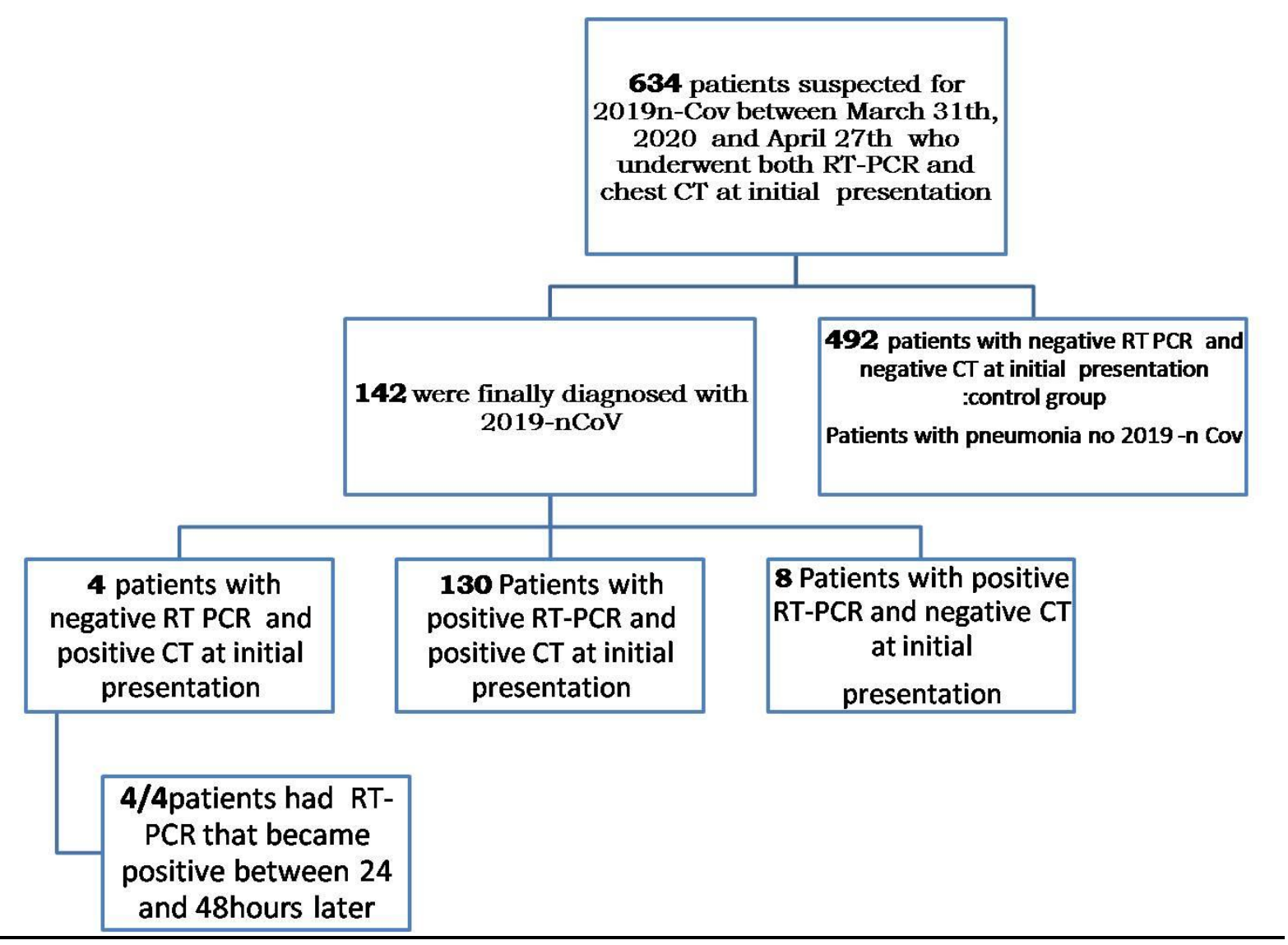

Fig1: Patient Flowchart: Of 142patients $4(2,8 \%)$ had negative RT PCR and positive CT at initial presentation 


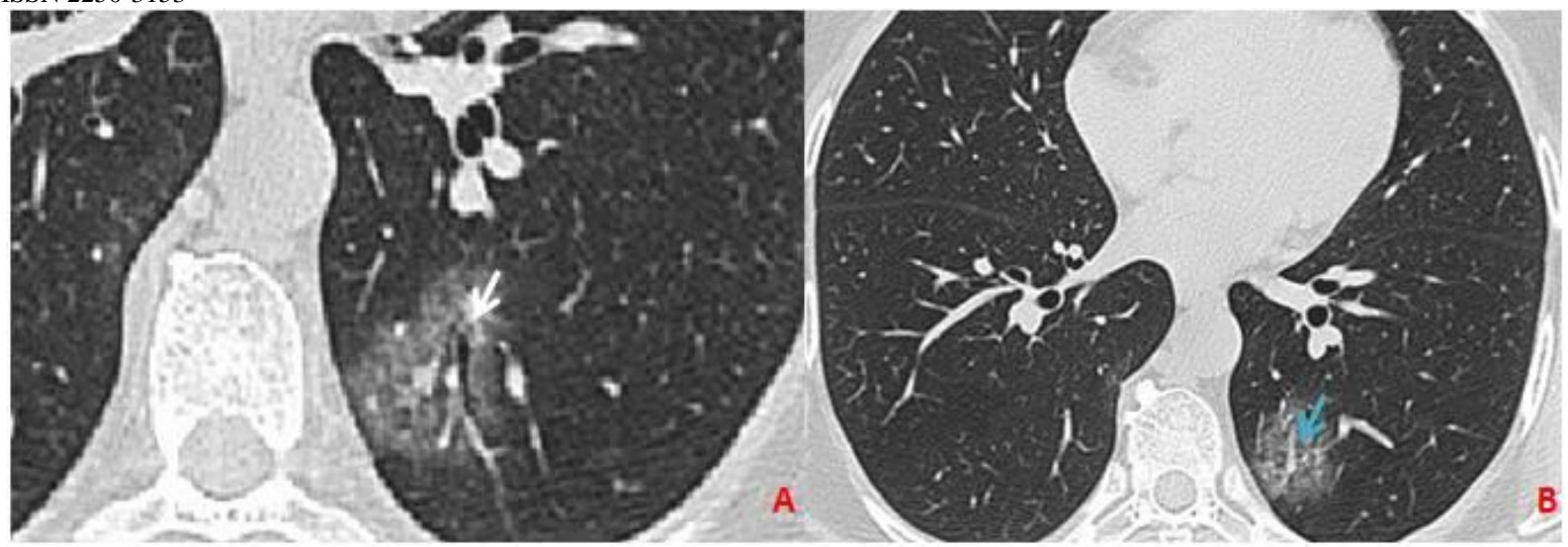

Fig 2: Chest CT imaging of patient 1.A-B,CT images show unilateral GGO lesion in the left lower lobe, traction bronchectasies(white arrow) and vascular enlargement are also seen(blue arrow). CT score involvement $<5 \%$; corad 4 .

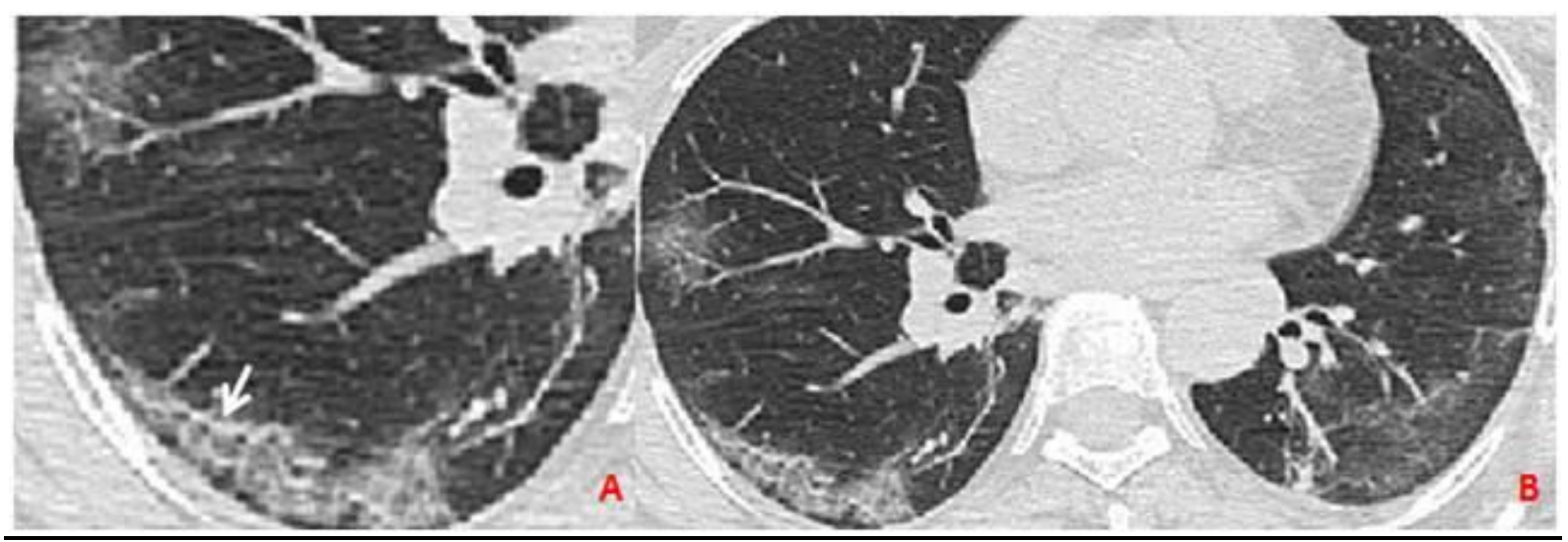

Fig 3: An axial CT images A-B obtained without intravenous contrast of Patient 2 Showed bilateral peripheral ground-glass opacities with interlobular septal thickening (white arrow) (crazy-paving pattern) that affected right lower lobe. CT score involvement 26\%-49\%; corads 5.

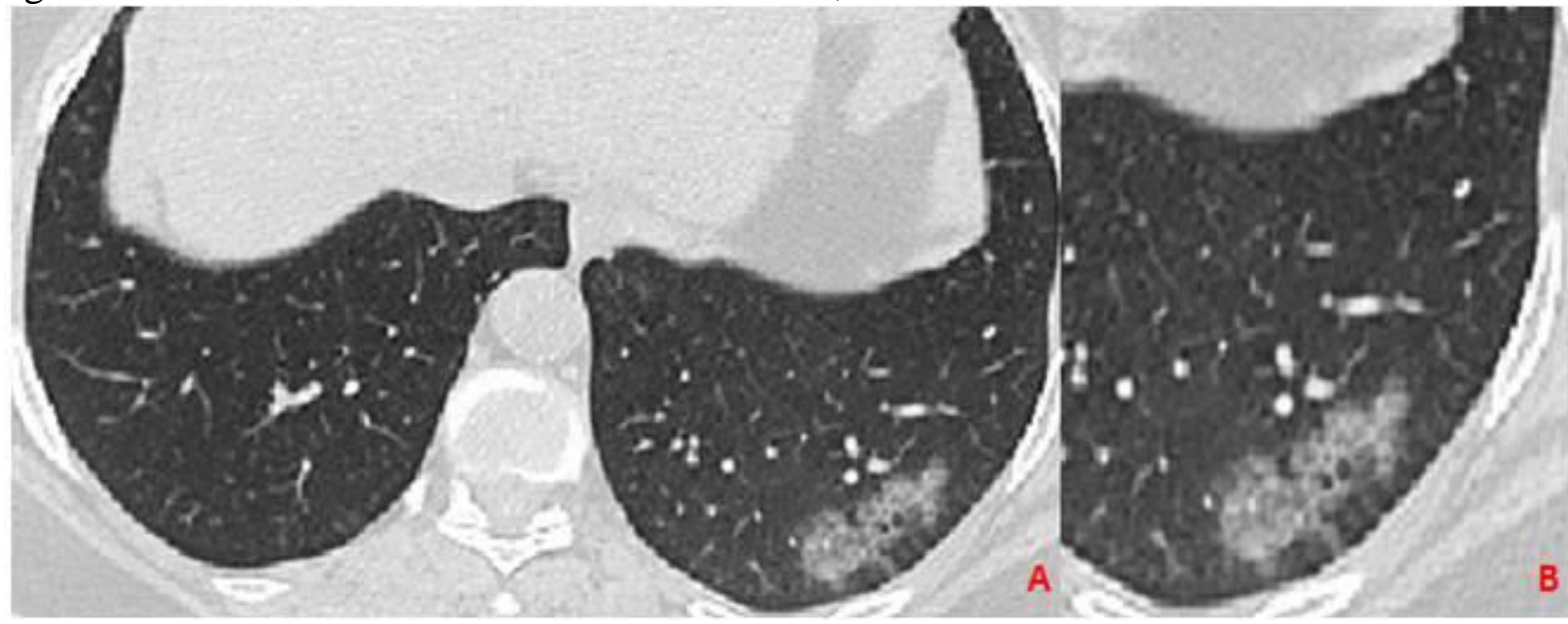

Fig 4: CT images (A-B) of patient 3 shows slight reticular pattern in the left lower lobe in subpleural area resembling the sign of crazy paving . CT score involvement $<5$, corads 4 . 

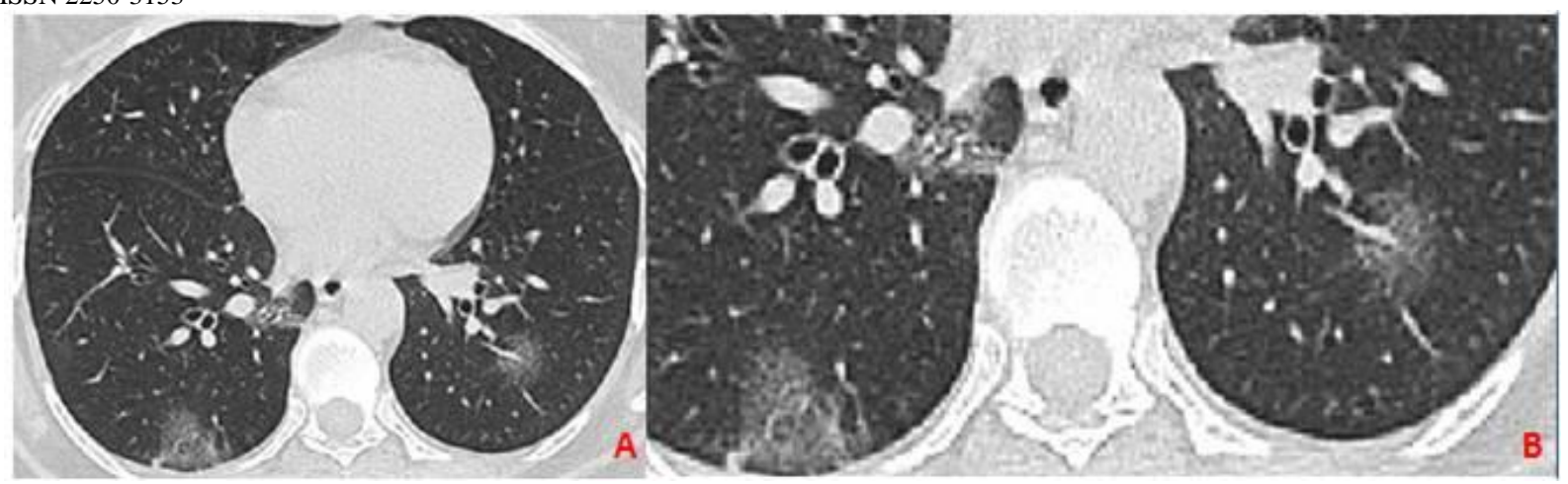

Fig 5: axial non contrast CT images $(A-B)$ of patient 4 shows ground glass opacities in the bilateral lower lobes . CT score involvement $5 \%-25 \%$, corads 5

Keywords:Pneumonia, Tomography ,Coronavirus.

Abbreviations:

CT:Computed tomography

rRT-PCR:Real time reverse -transcriptase -polymerase chain reaction

GGO:Ground glass opacities

Covid 19:Coronavirus disease 2019. 